\title{
А. А. АРХИПОВА
}

Архипова Анастасия Андреевна научный редактор, Издательский дом Высшей школь эконолики Россия, 117418, Москва, ул. Профбсоюзная, 33, корп. 4

Тел.: +7 (495) 772-95-90*12324 E-mail: anastasia.arkhe@gmail.com

\section{КАМЕНЬ ПРЕТКНОВЕНИЯ ИЛИ СКАЛА СКАНДАЛА? (КАК ГОВОРИТЬ О ТЕАТРЕ С ПОМОЩЬЮ ПСИХОАНАЛИЗА)}

Рецензия на: Théâtre et psychanalyse: Regards croisés sur le malaise dans la civilization / Sous la dir. de C. Page, C. Koretzky, L. Jodeau-Belle. — Montpellier: L'Entretemps, 2016. — 334 p.

П сихоанализ, подобно двум Афродитам из платоновского «Пира», небесной и земной, «пошлой», часто воспринимается в двух своих ипостасях — вульгарной и высоколобой. Психоанализ в духе голливудских фильмов и анекдотов про «Эдипов ${ }^{1}$-шмедипов» комплекс кажется настолько простым и очевидным, что оперировать его понятиями берется любой. Даже в серьезных текстах постоянно попадаются вездесущие словечки «фрейдизм» и «подсознание» - хотя «фрейдизмов» как вариантов бытования психоанализа после Фрейда на самом деле чрезвычайно много, а бессознательное Фрейда представляет собой парадигму, принципиально отличную от концепта подсознания у Пьера Жане [Архипов 2014].

В высоколобости, снобизме, элитарности, пифийской загадочности то и дело упрекают психоанализ лакановского толка, который когда-то, в 1970-, 1980-, в начале 1990-х был влиятельным дискурсом во Франции, а с конца 1990-х стал постепенно маргинализироваться. Лаканисты слывут высокомерными умниками, не обладающими элементарными компетенциями психологов - умением проводить тесты. Психоанализ клеймят за «ненаучность», его серьезно атакуют представители когнитивнобихевиорального направления в психотерапии; психоаналитикам пытаются чуть ли не законодательно запретить работать с аутистами (хотя именно лакановский психоанализ располагает уникальными инструмен-

${ }^{1}$ В существующих переводах работ 3. Фрейда принято написание Эдипов комплекс (с прописной). В литературе лакановского психоанализа, как правило, употребляется вариант Эдип в значении 'Эдипов комплекс'. Это связано с тем, что Эдип представляет собой фундаментальную структуру, так называемый узел субъекта, а не один из комплексов (или видов патологии), как, например, в юнгианской парадигме (где понятие комплекса используется в ином значении - комплекс Электры, анимус, анима и т. п.) или в индивидуальной психологии А. Адлера (комплекс неполноценности). 
тами работы с психозами и аутизмом), а бывшие последователи пишут разоблачительные труды в духе «Черной книги психоанализа» Миккеля Бок-Якобсена.

Факультет лакановского психоанализа, созданный при жизни Лакана в стенах некогда скандального и радикального парижского университета Париж-8 практически сразу после основания университета вослед событиям 1968 г., утратил былую славу: аналитики враждуют с факультетом психологии и выдают дипломы, имеющие лишь декоративную ценность. Университет Ренн-2 - один из немногих оплотов психоанализа во Франции, где психоаналитики удачно маскируются на факультете психологии под вывеской кафедры «Исследования в области психопатологии, новых симптомов и социальной связи». Студенты-психологи (по-видимому, не всегда безосновательно) жалуются, что преподаватели навязывают им лакановский дискурс, сыплют непонятными терминами, не утруждают себя объяснениями, напоминают скорее приверженцев религии, чуть ли не сектантов, и вообще, «разве это наука?».

И вульгарный, и «снобский» психоанализ - полупародийные отсветы той скандальности, которая заложена в самой природе психоанализа. Аура скандала окутывала и в высшей степени респектабельного Фрейда, и в высшей степени эксцентричного Лакана, на чьи семинары в пору их расцвета ходили как в театр одного актера: семинары стали знаменитыми и модными после нашумевшего отлучения мэтра от Международной психоаналитической ассоциации (Лакан, провозгласивший «возвращение к Фрейду», открыто критиковал «англо-саксонскую» версию психоанализа с ее медицинским и педагогическим уклоном, укреплением эго и нормализацией).

Психоанализ как практика имеет дело с самым интимным, скандальноневыносимым, с тем, что человек бессознательно скрывает от себя самого, психоаналитик расставляет пунктуацию в потоке речи пациента, пускает в ход уловки, останавливая «пустую речь», провоцируя речь бессознательного. Об одном своем пациенте Лакан говорит:

...благодаря экспериментам с короткими сеансами [нам удалось] обнаружить у субъекта мужского пола фантазм анальной беременности и сновидение о разрешении от нее путем кесарева сечения; не сделай мы этого вовремя, нам пришлось бы выслушивать его рассуждения об искусстве Достоевского до сих пор [Лакан 1995: 85].

Истерички своими загадочными болезнями, не имеющими соматической причины, раздражали добропорядочных эскулапов: те объявляли их симулянтками, кривляками и бездарными комедиантками. И только Фрейд догадался начать их выслушивать. Так происходит рождение психоанализа, истина которого располагается в области субъективного, не подчиняясь объективным, «научным» законам. Психологическими тестами ее, действительно, не измеришь.

О скандальности психоанализа сам Фрейд неоднократно упоминает с неизменным юмором. В публичных лекциях о психоанализе 1915-1917 гг. он рассказывает анекдотическую историю. Его коллега-психоаналитик, находясь в качестве врача на немецком фронте, заинтересовывает врачей корпуса учением психоанализа, и те каждый вечер собираются, чтобы послушать его лекции. 
Какое-то время все идет хорошо, но после того как он рассказал слушателям об Эдиповом комплексе, встает один начальник и заявляет, что этому он не верит, что гнусно со стороны докладчика рассказывать такие вещи им, бравым мужчинам, борющимся за свое отечество, и отцам семейства, и что он запрещает продолжение лекций. 〈... Удивительно, что трагедия Софокла не вызывает у слушателя по меньшей мере возмущенного протеста, сходной и гораздо более оправданной реакции, чем реакция нашего простоватого военного врача. Потому что, в сущности, эта трагедия - безнравственная пьеса, она снимает с человека нравственную ответственность, показывает божественные силы организаторов преступления и бессилие нравственных побуждений человека, сопротивляющихся преступлению [Фрейд 1991: 210-211 (лекция 21)].

У истоков психоанализа, как мы видим, стоят не только истерички, в тяжеловесной американской психоаналитической классификации именуемые, кстати, «гистрионными (histrionic) личностями». В начале была драма - драма Эдипа.

\section{На подмостках бессознательного}

Французское издательство «L'Entretemps», специализация которого - книги о сценическом искусстве, выпустило при поддержке Университета Ренн-2 сборник статей под названием «Театр и психоанализ: на перекрестке взглядов на неудобства культуры». В книгу вошло более 20 статей, написанных французскими (или, во всяком случае, франкофонными) психоаналитиками лакановской ориентации, театроведами, музыковедами и литературоведами, а также ряд интервью, взятых психоаналитиками у режиссеров и актеров. В числе психоаналитиков такие известные в среде лаканистов имена, как Эрве Кастане, Клотильда Легиль, Летиция Жодо-Белль (одна из составителей), Пьер Наво, Мари-Элен Брусс, Софи Марре-Мальваль и др.

Подзаголовок книги — «Regards croisés sur le malaise dans la civilization» - отсылает к работе 3. Фрейда «Das Unbehagen in der Kultur» (1930), в русском переводе «Неудобства культуры» (Р. Ф. Додельцев) или «Недовольство культурой» (А. М. Руткевич). Во французском переводе названия фрейдовской статьи («Malaise dans la civilisation») немецкому слову Unbehagen соответствует французское malaise, подчеркивающее одно из значений Unbehagen — 'недомогание'; причиной этого недомогания, болезненного дискомфорта и даже невротических страданий становится цивилизация, препятствующая нашим детским сексуальным и агрессивным влечениям.

Заголовок и подзаголовок издания звучат заманчиво: составители в общем введении к объемному тому обещают показать, как «театр и психоанализ, каждый на свой лад, затрагивают измерение, отличное от измерения красоты, желания и идеала, и создают замешательство, сдвиг, выводя на сцену недомогания цивилизации» (р. 11-12). Печатью скандальности - как и в случае психоанализа, связанной с вопросами пола, - отмечен и театр времен Фрейда: среди «безнравственных пьес» авторы сборника упоминают, хотя и в сноске, «Фрекен Жюли» Стриндберга и «Пробуждение весны» Ф. Ведекинда. Доста- 
точно вспомнить впечатляющий текст Ведекинда, написанный в 1891 г. (когда Фрейд еще находится в орбите «катартического метода» Йозефа Брейера, использует гипноз, а не свободные ассоциации, и даже само слово психоанализ пока не родилось) и перенесенный на сцену театральным реформатором Максом Рейнхардтом только в 1906 г. (когда уже созданы «Толкование сновидений», «Три очерка по теории сексуальности», «Психопатология обыденной жизни»), чтобы понять, насколько точно психоанализ попадает в нерв эпохи и одновременно сам является ее порождением. Здесь мы подходим к еще одному положению, от которого отталкиваются в своей концепции составители сборника, - художники опережают психоаналитиков, прокладывая им путь. Психоанализ подтверждает то, «о чем всегда говорили поэты и знатоки человеческой природы», скажет Фрейд в своей «Автобиографии» (1925). В работе «Бред и сны в “Градиве” И. Иенсена» (1907) он пишет:

Художники — ценные союзники 〈...〉. Даже в знании психологии обычного человека они далеко впереди, поскольку черпают при этом из источников, которые мы еще не открыли для науки» [Фрейд 1995: $139]$.

Предыстория психоанализа - это истерический театр Ж.-М. Шарко, демонстрировавшего студентам (в том числе молодому Фрейду) и коллегам причудливое поведение своих пациенток в «Мекке неврологов», парижской больнице Сальпетриер. «Частным театром» называла свои сновидения наяву знаменитая пациентка Брейера, вошедшая в анналы психоанализа под именем Анны О. [Фрейд, Брейер 2005: 40]. Не менее знаменитый пациент Фрейда, так называемый Маленький Ганс (настоящее имя Герберт Граф), герой «Анализа фобии одного пятилетнего мальчика», повзрослев, снискал славу оперного режиссера, ставившего в «Метрополитен-опере», «Ла Скала» (для Марии Каллас), «Ковент-Гардене», в Зальцбурге.

Самое растиражированное понятие психоанализа, Эдипов комплекс, восходит к трагедии Софокла «Царь Эдип». Фрейд присутствовал на венских гастролях прославленного спектакля Макса Рейнхардта по «Царю Эдипу» (1911) - и, судя по всему, эта постановка произвела на него впечатление [Armstrong 1999].

Фрейд размышлял о Гамлете и о том, каким критериям должна удовлетворять психопатология персонажа, чтобы его можно было вывести на сцене, не лишив зрителя причитающегося ему катарсиса ${ }^{2}$. Жак Лакан посвящает «Гамлету» семь занятий своего семинара «Желание и его интерпретация» (Семинар VI, 1958-1959). Еще одна трагедия Софокла - «Антигона» - берется Лаканом за основу семинара «Этика психоанализа» (Семинар VII, 1959-1960).

Психоаналитики и художники пользуются подчас общими сюжетами, выхватывая «кейсы» непосредственно из жизни. Так, по следам взбудоражившего общественность невероятно жестокого убийства, совершенного сестрами Папен в 1933 г. в городке Ле Мане (сестры-служанки в приступе ярости убили своих хозяек), Лакан публикует в журнале своих друзей-сюрреалистов

${ }^{2}$ «Толкование сновидений», «Царь Эдип и Гамлет», «Психопатологические персонажи на сцене». 
«Минотавр» статью «Мотив паранойяльного преступления: преступление сестер Папен» [Lacan 1933], а в 1947 г. по мотивам этого события будут созданы «Служанки» Жене. И хотя Жене всегда упорно отрицал какое бы то ни было влияние дела Папен на замысел пьесы, именно произведенный Лаканом анализ причин этого на первый взгляд совершенно необъяснимого происшествия позволяет увидеть, что механизмы паранойяльной зеркальной (нарциссической) идентификации, описанные Лаканом в связи со случаем Папен, работают и в пьесе Жене.

Психоанализ заимствует театральный вокабуляр, формулируя с его помощью свои важнейшие понятия: первичная сцена (подвергшееся вытеснению фантазийное осмысление ребенком травматической для него воображаемой или реально увиденной сцены сексуальных отношений между родителями); другая сиена (сцена, на которой разворачивается сновидение).

Термин другая сиена (der andere Schauplatz) применительно к сновидению принадлежит психофизиологу Т. Г. Фехнеру: Фрейд воспользовался им в «Толковании сновидений» для обозначения системы бессознательного, радикально гетерогенной по отношению к системе сознания. Персонажи, действующие на этой сцене, - образования бессознательного (сны, остроты, фантазии, симптомы). На этих подмостках в замаскированном обличии появляется желание ${ }^{3}$, разыгрывающее то фарс, то трагедию, чтобы ускользнуть от бдительного ока Суперэго: его маски - это пластические образы сновидения, языковые ребусы, обретающие визуальную форму по законам сгущения и смещения (Лакан отождествит их с якобсоновскими метафорой и метонимией).

Лакан продолжает активно развивать метафору Фрейда, еще больше «театрализируя» ее. Бессознательное, «другая сцена», структурировано как язык. Язык - это «сцена высказывания», на которую выходят «вещи мира», согласно «законам означающего» [Лакан 2010: 44]. Мы существуем внутри «фикции», виртуальной системы языка: «с̧а parle», «оно говорит» (Оно, фрейдовское Id). Человека-Крысу (один из пяти больших анализов Фрейда) преследует навязчивая фантазия о крысах, он захвачен страшной сценой, которую вынужден проигрывать вновь и вновь. Означающее буквально, как крыса, вгрызается в его тело: все мучения пациента сконцентрированы в метафорическом сгустке, языковом ребусе, сложившемся из метонимических обломков семейных означающих, объединенных элементом rat 'крыса' : долговой платеж' (Rate); отец — заядлый игрок (Spielratte); жениться (heiraten).

Вхождение в язык - «неудобство культуры», именуемое у Фрейда кастрацией. Отныне субъект (субъект в лакановской терминологии - это субъект бессознательного; он не равен «я», «личности», «индивидууму») будет связан с запретным для него (инцестуальным, по Фрейду) наслаждением особыми отношениями, которые носят у Лакана название фантазма. Фантазм - это бессознательный с ц е н а р и й, организующий отношения человека с миром и ориентирующий его желание, причина которого - вечно ускользающий объект (objet petit a, «объект $a »)$, запретное наслаждение.

Фантазм Лакан уподобляет завесе, вуали (подобной покрывалу, скрывающему статую Изиды в «Саисском изваянии» Шиллера) - вуаль скрывает

\footnotetext{
${ }^{3} \mathrm{Coн,} \mathrm{по} \mathrm{Фрейду,} \mathrm{—} \mathrm{это} \mathrm{исполнение} \mathrm{бессознательного} \mathrm{желания.}$
} 
объект $a$. Тревога возникает не там, где объект недоступен, а там, где этот объект внезапно появляется, разрывая завесу. Образуется зияние, в котором обнаруживается нечто жуткое: сквозь распахнутое окно семеро волков, расположившихся на ветвях дерева, неподвижным взором глядят на сновидца в детском сновидении русского пациента Фрейда, Человека-с-волками. Завеса, вуаль - но она же и театральный занав ес, поднятию которого предшествует «краткое мгновение тревоги»: «без этого краткого, предваряющего театральное действо мига тревоги ни трагическое, ни комическое на сцене не состоится» [Лакан 2010: 94].

Фантазм - это и сцена, и то, что на ней разыгрывается. Он вбирает в себя текст, сценарий, драматургию; образы, в которых этот сценарий воплощается (в фантазме всегда присутствует измерение зрения и зрелища); и запретное наслаждение, загадку «первичной сцены», ответом на которую и является фантазм [Quinet 2010].

\section{«Fécondes copulations» и где они обитают}

Мы предприняли это развернутое вступление в попытке продемонстрировать, что язык психоанализа - не философский и не университетский дискурс, не научный инструментарий, а язык клиники, в каждом новом случае имеющей дело с уникальным, а не нормативным. В определенном смысле психоанализ с каждым пациентом изобретается заново. Художественные тексты и явления искусства психоанализ не столько анализирует, сколько использует их как сокровищницу знания, из которой он извлекает свои концепты, попутно выявляя и подчеркивая сходство своего языка с языком искусства. Об этом, собственно, говорят составители сборника в предисловии:

Эта книга не является примером драматургического анализа и не стремится выстроить иерархические отношения между полем театра и полем психоанализа; ее задача — разглядеть во встрече театра и психоанализа возможность плодотворного союза (fécondes copulations), который обещает творческое наслаждение, непрестанно обновляющееся вслед за переменами в обществе (р. 10-11).

Книга состоит из пяти больших тематических разделов: «Психоанализ и его двойник»; «Удовольствие от текста, наслаждение означающим»; «Другая сцена: сновидение и желание»; «Лакан — читатель театральных текстов»; и «Потрясения (tumultes) наших дней: “Если небесных богов не склоню - Ахеронт всколыхну я"» ${ }^{4}$. Каждому предпослано небольшое введение с краткой «программой». Программа первого раздела — театр, современный Фрейду: Артур Шницлер и А.-Р. Ленорман, живо интересовавшиеся психоанализом, Ибсен, неоднократно упоминавшийся Фрейдом ${ }^{5}$ Оскар Уайльд. Фрейд рассматривается как мыслитель, артикулировавший в терминах того, что сам он

\footnotetext{
4 Эту цитату из «Энеиды» Фрейд поставил эпиграфом к «Толкованию сновидений».

${ }^{5}$ См., например, подробный разбор драмы «Росмерсхольм» в статье «Некоторые типы характеров из психоаналитической практики» или упоминание «Маленького Эйольфа» в случае Человека-Крысы.
} 
продолжает называть «наукой», измерение бессознательного, интерес к которому проявился в эстетике модернизма (например, под именем «психологизма», «драмы личности»). Язык психоанализа становится, с одной стороны, инструментом дешифровки смыслов искусства, а с другой - одним из новых способов художественной выразительности, или, как пишет Ленорман, «волшебный ключ психоанализа открыл нам потайные комнаты, полные сокровищ и чудовищ. Мы же - их преданные и прилежные посетители» («Исповедь драматурга») (р. 24) ${ }^{6}$.

Во втором разделе на примере театра Жоржа Фейдо, Пикассо, Пазолини и Ибсена рассматривается диалектика удовольствия и наслаждения: удовольствие от расшифровки текста и смыслов бессознательного, от попыток уловить ускользающее желание; и наслаждение, которое всегда «по ту сторону принципа удовольствия», - если угодно, удовольствие в страдании, отсылающее к влечениям и телу. Желание обнаруживает себя в авторском стиле, порождающем удовольствие от текста; а наслаждение - в том, что не дешифруется, лежит по ту сторону смысла, в невозможном, невыразимом. Наслаждение находит воплощение в образе ибсеновской Гедды Габлер. Лакан называет это загадочное наслаждение «женским» (или «мистическим»), отвечая тем самым на вопрос, который поставил в свое время Фрейд, признаваясь, что ему так и не удалось найти на него ответ: чего хочет женщина?

Третья часть посвящена «другой сцене»: благодаря работе сновидения, которую производит сновидец, инсценируется текст, исключенный из жизни бодрствующей. Текст (скрытое желание) воплощается в образах-ребусах, чтобы обойти цензуру Суперэго. Абсурдные образы сновидения кажутся сновидцу чуждыми, отторгнутыми от него самого, свидетельствуя тем самым о расщеплении субъекта в языке. Но в то же время они задают новую оптику, высвечивая самое интимное в субъекте, истину его желания. Отчужденное и интимное парадоксальным образом накладываются друг на друга. Внутреннее овнешняется. Театр можно рассматривать как один из способов такого овнешнения; но в отличие от сновидения, которое существует только в пересказе, театр создает зримое пространство, где зрители оказываются в роли коллективного сновидца.

В четвертой части речь идет о том, как Лакан работал с различными театральными текстами, делая их отправной точкой для развертывания основных положений своей теории. Так, из «Антигоны» (семинар VII) он извлекает этику психоанализа; из «Гамлета» (семинар VI) — трагедию человеческого желания; «Балкон» Жене (семинар V) нужен ему, чтобы продемонстрировать концепт фаллоса, а трилогия Клоделя («Заложник», «Черствый хлеб», «Униженный отец») — понятие объекта (семинар VIII).

Наконец, в завершающем разделе дело доходит и до «потрясений» на европейской театральной сцене наших дней:

...начиная с Арто театр вошел в состояние глубочайшего бурления, возбуждения. Речь идет о взбудораженности тела, тела артиста, о котором грезил Арто: тело, разрывающее покров красоты, чтобы вернуть слову его силу, «вырвать его из психологического прозябания»

${ }^{6}$ Lieber G. Théâtre et psychanalyse chez Henri-René Lenormand (1882-1951). 
[«Театр и его двойник»]. Жестокость для Арто - это поиск такой перформативности, благодаря которой зритель перестает быть просто зрителем (р. 266).

Связь с прежней эстетической парадигмой разорвана, происходит смешение и деиерархизация жанров и категорий, радикально перестраиваются отношения со зрителем. «Живой спектакль разворачивает перед глазами зрителя то, что некогда было скрыто от него под завесой, вуалью, и это порождает эффект тревоги» (р. 266). То, что таилось под завесой, - это объект $a$, или в л е ч е н ч е с к и й объект: в лакановском психоанализе их насчитывается несколько разновидностей — фрейдовские оральный, анальный, фаллический и добавленные к ним объект-взгляд и объект-голос ${ }^{7}$. Уже не зритель глядит на сцену, а сцена глядит на него: взгляд обнаруживает свое прежде скрытое присутствие, завораживающую силу взгляда Медузы. Таковы спектакли Ромео Кастеллуччи или Яна Фабра.

\section{Арто, да не то}

На какого адресата рассчитаны тексты, собранные в этих многообещающих разделах? Неподготовленный читатель сразу сталкивается с щедрой россыпью практически никак не поясняемых терминов и понятий - а между тем они составляют основу концептуального аппарата, с помощью которого авторы сборника демонстрируют нам особенности психоаналитического метода. И персонажи, и авторы текстов (среди которых не только психоаналитики), и даже интервьюируемые режиссеры - все говорят на диалекте, именуемом «лакановский психоанализ». Режиссеры, среди которых, например, нынешний директор Авиньонского фестиваля Оливье Пи и директор «Одеона» Стефан Брауншвейг, с энтузиазмом, близким к неофитскому, рассказывают о своем знакомстве с психоанализом, опыте личного анализа, детских фобиях, своих родителях, рассуждают о бессознательном, желании, переносе, языке, трех лакановских регистрах символического, воображаемого и реального, Суперэго, влечениях и даже о «субъекте якобы знающем» (sujet supposé savoir). Такая осведомленность, несомненно, впечатляет (хотя и производит подчас несколько комический эффект), а сопоставление в этих интервью театральной модели с психоаналитической (режиссер в качестве аналитика, вслушивающегося в бессознательное текста; «желание» внутри текста; бессознательное в зрительном зале; театр-сновидение, театр как пространство «бесконечного анализа» и психоаналитическая ситуация как сцена) выглядит вполне убедительным и во всяком случае приглашающим к размышлению.

Впрочем, не оставляет ощущение некоей «сделанности» этих бесед (не говоря уже о том, что знание психоанализа, причем в его лакановской версии, оказывается по сути критерием отбора собеседников). Психоанализ как клинический метод нацелен на остановку в речи, мгновенный проблеск уникального означающего, эффекта истины. Эффект истины отличается от истины как абсолюта именно этой крайней подвижностью: истина промелькивает в устье

${ }^{7}$ В клинике психозов объект-взгляд и объект-голос будут представлены, например, преследующим взглядом и голосами в галлюцинациях. 
бессознательного, которое, едва приоткрывшись, тут же захлопывается. Поэтому интервью будет ценно не столько своей сознательной сконструированностью в рамках предложенной темы, сколько этим эффектом бессознательного «проскакивания искры». Например, тот же Оливье Пи рассказывает о «сверхчеловеческом», по его выражению, режиме функционирования тела на сцене: актер на сцене или на съемках существует как бы вне своего собственного тела. Пи, страдающий панической боязнью змей, на съемочной площадке полностью забыл о своей фобии, когда по роли ему надо было иметь дело с живой змеей; в другом случае актриса, играя роль, провела на площадке час, не подозревая, что у нее сломана нога (р. 168-169). Эти миниэпизоды могли бы открыть возможность для плодотворного обсуждения, в связи с опытом пребывания на сцене, одной из важнейших тем лакановского психоанализа: статус тела воображаемого и реального. Сценический опыт получил бы любопытное осмысление в клинических категориях, в то же время психоаналитический концепт мог бы быть прояснен с помощью уникального материала.

Возможных точек сборки (и, наоборот, разломов, точек сопротивления материала слишком поверхностным аналогиям и интерпретациям), где психоаналитический метод мог бы быть продемонстрирован наиболее выигрышным образом, можно насчитать немало - как ни удивительно, чаще всего они полностью игнорируются. То, что могло бы превратиться в исследование о событии спектакля (постановки французского режиссера Алэна Франсона, с которым предпочитает работать английский драматург Эдвард Бонд), распадается на два текста в традиционных жанрах: интервью с Франсоном ${ }^{8}$ и анализ драматургии Бонда9 ${ }^{9}$ Тут нужно отметить, что в большинстве представленных в книге статей и диалогов с режиссерами / актерами театр понимается преимущественно как текст «с идейным содержанием» и игрой языка; из исследовательского фокуса практически выпадают такие ключевые параметры театрального, как перформативность, визуальность, телесность, зрительское присутствие. Разбор «Гедды Габлер» ${ }^{10}$ как случая истерии и иллюстрации к понятию женского наслаждения остроумен и логичен - но непонятно, чем он отличался бы от аналогичного разбора, например, образа Эммы Бовари, который можно было предпринять в том же русле.

Стремление всё отмыкать «волшебным ключом психоанализа» часто уводит по ложному следу. Например, при анализе пьесы Уайльда «Как важно быть серьезным» ${ }^{11}$ акцент ставится на Эдипе, Имени-Отца и «невозможности сексуальных отношений» (еще одно важное парадоксальное понятие лакановского психоанализа, вводимое без предварительных пояснений), в то время как другой «ключ» лежит на поверхности - в работе Фрейда «Остроумие и его отношение к бессознательному». Разумеется, тема остроумия и его механизмов не была обойдена стороной в статье; но самое ценное для наших целей в тексте Фрейда то, что он выявляет театральный диспозитив в самой ситуации рассказывания остроты - здесь есть остряк, который не смеется

${ }^{8}$ Alain Françon. Perdre le fil (p. 142-146).

${ }^{9}$ Jullien B. Le théâtre d'Edward Bond: un theater de l'acte (p. 268-274).

${ }^{10}$ Vinciguerra R.-P. Hedda Gabler, une femme inabordable (p. 90-97).

${ }^{11}$ Boileau N. P. CEdipe Roi: Du social au sexuel dans L'importance d'être Constant d'Oscar Wilde (p. 41-50). 
своей остроте, есть объект остроты, и есть третий участник, слушатель, которому и передоверена функция смеха. Пьесу Уайльда можно было бы рассмотреть как машину, порождающую непрекращающийся фейерверк абсурдных острот («сдвиг и бессмыслица», в классификации Фрейда), почти стендап, где взаимодействие со зрителем мгновенно, и оно тесно связано с формой высказывания; отсюда любопытнее было бы проторить дорожку не к абстрактному Эдипу, а к личному провокационному театру Уайльда с зеленой гвоздикой, Уайльда в костюме Саломеи, Уайльда на судебном процессе...

Метод психоанализа, выявляющий сочленения интимного и универсального, можно было бы эффектно развернуть именно там, где клиническое измерение переходит в художественное. Психоанализ, похищающий лавры у классической психиатрии, предлагая взамен классификационного феноменологического подхода - структурный, создает такую клинику психозов, где психотический субъект рассматривается не как патологический и отклоняющийся от нормы, а как создающий особые, весьма изобретательные отношения с Другим (языком). Такое изобретение Лакан называет sinthome (в отличие от симптома, звучание которого по-французски здесь каламбурно обыгрывается) и рассматривает его на примере сочинений Джойса в семинаре «Le sinthome» (1975-1976).

Психотическая структура Жене, Беккета, Арто ${ }^{12}$ (и, например, Вацлава Нижинского $^{13}$ ) непосредственно монтируется с их открытиями, повлиявшими на судьбу европейского театра. Ясное, просветительское по своим задачам исследование этих монтажных стыков куда уместнее смотрелось бы в книге с фундаментальным названием «Театр и психоанализ» (если предположить, что обращена она все-таки скорее к «граду и миру», а не к эзотерическому сообществу психоаналитиков), нежели представленные в ней тексты о Жене и Беккете ${ }^{14}$, в которых одно неизвестное описывается через другое, замкнутым на себя языком лаканизмов, то слишком загадочным, то, напротив, излишне мимикрирующим под «обычный» язык (по принципу sapienti sat — лаканист и так поймет, в каком смысле употребляются слова «отец», «тревога», «Бог», «господин и раб», «боль существования», «голос» и т. д.). Арто же и вовсе упомянут лишь вскользь.

Наконец, удивительным образом в сборнике совершенно обойден вопрос о механизме переноса - хотя он тут напрашивается сам собой как возможная модель осмысления взаимоотношений зрителей со сценическим действом. Между тем именно проблема реагирования зрителя на происходящее на сцене находится в фокусе текстов Фрейда, посвященных театру: например, при каких условиях работает или не работает катарсис, как заинтересованность зрителя спектаклем соотносится с детской игрой и т. д. В проводимом им различении между художественным как сублимативным и «психопатологическим»

12 Тексты лакановских аналитиков об этих художниках в таком ключе, конечно, существуют; например, Фабьен Юлак в книге [Hulak 2016] разбирает в том числе случай А. Арто (глава «Antonin Artaud, l'hérétique du surréalisme»). Эрве Кастане - автор книги о Жене [Castanet 2015]. См. также: [Guéguen 2009].

${ }_{13}^{13}$ См.: [Wachsberger 1997; Menghi 2008; Архипова 2015].

${ }^{14}$ Naveau P. Quand vient le temps de la fin (p. 236-242); Malengreau P. Lacan, lecteur de Genet (p. 223-234). 
как прорвавшим преграду вытеснения ретроспективно можно разглядеть предвестие грядущих процессов в театре - хотя сам Фрейд ограничен традиционными, «аристотелевскими», категориями, и для него «психопатологическое», т. е. страдание (namoc), не работающее на зрительский катарсис и удовольствие, выпадает за рамки художественного, превращаясь в медицинский случай, и тогда остается только «как и в реальной жизни, послать за доктором и объявить этот персонаж непригодным для сцены» [Freud 1953: 310].

Фрейдовский проект - просветительский: каждый его текст - это лаборатория мысли, где читателя посвящают в живой, захватывающий, всегда интригующий процесс рассуждений автора, превращая его в полноценного собеседника. Фрейд предлагает свою интерпретацию, попутно обучая читателя самому методу интерпретации. Тексты Фрейда - диалогические по своей сути: зачастую он и выстраивает их в виде платоновского диалога («К вопросу о дилетантском анализе») или в форме публичных лекций для непрофессионалов. Тексты Лакана - виртуозные, барочные (изобилующие, по его выражению, «гонгоризмами»), поэтические, парадоксальные, театрализованные (обращенные к публике знаменитых семинаров). В своей теории дискурсов Лакан отличает психоаналитический дискурс от университетского: университет претендует на полноту знания, знание психоанализа - бессознательное, всегда неполное. Клиника, соотнесенная с этикой желания, сопротивляется теории. Как сохранить баланс между методом клиническим и методом критическим, не соскальзывая в дидактизм и скуку респектабельного знания, говорящего из позиции господина?

\section{Содом и Гоморра совриска}

И все же в нашей книге нашлись «два праведника», из-за которых можно пощадить весь город.

Во-первых, это ясная и увлекательная статья Клотильды Легиль «От Фейдо до Лакана: безумие означающего» (р. 62-72), в которой на примере драматургии Жоржа Фейдо демонстрируется природа означающего, «паразитирующего», по выражению Лакана, на человеческом теле: означающее безумствует, прихотливым образом соединяясь с другими означающими, подчиняя себе жизнь субъекта, который не может «ни желать того, о чем говорит, ни сказать, чего же он желает» (р. 69) (вспомним Человека-Крысу). Драма желания - это не только трагедия Шекспира, но и комедия Фейдо, в чьих нелепых персонажах мы опознаем собственную судьбу «говорящих существ».

Во-вторых, это текст Мари-Элен Брусс «Кастеллуччи, театр объектов» (р. 288-293), на котором мы сосредоточимся подробнее. Об эстетике Ромео Кастеллуччи М.-Э. Брусс размышляет в терминах клиники, попутно объясняя их читателю. Театр Кастеллуччи знаменует разрыв с «театром субъекта» персонажа, героя - в том числе и театра беккетовского. Какие же объекты имеются в виду? Объект(ы) $a$, отвечает М.-Э. Брусс, т. е. объекты влечения, которые субъект обнаруживает в опыте психоанализа. В случае Кастеллуччи театральный опыт воздействует на зрителя аналогично тому, как психоанализ воздействует на анализанта. 
В обоих случаях речь идет о появлении особых объектов, которые смешиваются с другими, «обычными» объектами, являющимися предметом желания и соперничества. 〈... Разница в том, что у Кастеллуччи эти объекты появляются непосредственно на сцене, в то время как путь аналитика куда более извилист. Через уникальные особенности своей речи, через разветвления свободных ассоциаций, долгим путем высказываний, порождающих фантазматические сценарии, которые разворачиваются во время анализа, субъект постепенно, шаг за шагом приближается к своим [влеченческим] объектам, в то время как в театре Кастеллуччи, напротив, зритель мгновенно обнаруживает себя в присутствии этих объектов, возникающих на сцене (р. 289).

В отличие от желанных обычных объектов, объекты $а$ радикально чужды нам, о чем «сигнализируют тревога или отвращение» (р. 291).

В спектакле «Юлий Цезарь» по шекспировской пьесе «тучные, дряхлые или аноректические тела - это сама плоть, а не образ ‘...>, реальный загадочный объект вне смысла» (р. 292); камера в горле одного из актеров проецирует на экран движения его голосовых связок - объект-голос, непостижимый, вне маскирующих его речи и смысла, во всей своей тревожной чуждости. В постановке «О концепции лика Сына Божьего» таким объектом являются экскременты: на фоне гигантского образа Христа работы Антонелло да Мессина - совершенного образа Сына - сын ухаживает за дряхлым, немощным, выжившим из ума, ходящим под себя (О)отцом, обращая к нему реплики, не получающие никакого отклика. Экскременты выходят из-под контроля, пачкая все вокруг: в конце концов анальный объект атакует идеальный образ, божественный лик Сына. Завеса Идеала разорвана, наступает «конец царства смысла» (р. 292).

Текст о Кастеллуччи - часть давнишнего проекта М.-Э. Брусс, занимающейся проблематикой современного искусства в контексте психоаналитической теории и клиники. В гранадской лекции «Лакановские тела: новое в современном искусстве и стадия зеркала» [Brousse 2009а] и в статье «Объект искусства в эпоху конца Прекрасного» [Brousse 2009b] она прослеживает связь между дискурсом науки и современным искусством, исходя из клинического понятия стадия зеркала ${ }^{15}$.

Отправная точка Прекрасного - собственное тело человека. Тело в психоанализе - воображаемая целостность, вбирающая в себя хаотический органический опыт, телесные ощущения благодаря посредничеству языка, речи Другого (матери, подносящей ребенка к зеркалу). Точки встречи между органическим опытом и образом - отверстия тела (рот, анус, фаллос, глаза, уши). Это пограничные зоны наслаждения, объекты $a$, которые позволяют образу «сцепиться» с организмом. Они завуалированы завесой красоты, смысла, идеала.

${ }^{15}$ Стадия зеркала - одно из ключевых понятий лакановской теории, фаза в жизни маленького ребенка, когда он, еще плохо владея своим телом, видит себя в зеркале, и эта иллюзия целостного образа, не соответствующая реальному состоянию его органического тела, вызывает у него ликование; так происходит первая идентификация (воображаемая основа эго). В клинике психозов можно часто встретить феномен распада зеркального образа, переживание воображаемой фрагментации, расчлененности собственного тела. 
Наука, которую интересует организм, изменяет наши отношения с телом как воображаемым и одновременно с телом как неизвестным нам организмом. Она срывает воображаемый покров с тела-организма; чем эффективнее наука, тем слабее Идеал, тем сильнее тревога. Объекты $a$ превращаются в обычные объекты, подлежащие циркуляции, обмену, коммерциализации (например, органы для трансплантации). Современное искусство фиксирует эти перемены в культуре. Брусс приводит в качестве самого наглядного примера работы Дэмьена Хёрста, где отменяется различие между символом и вещью, к которой он отсылает (композиция «Мать и дитя» - расчлененные корова и теленок в формалине; усыпанный бриллиантами настоящий человеческий череп - не символ vanitas, а сама тщета как вещь с рыночной стоимостью и т. п.).

Объекты искусства больше не блокируются преградой Прекрасного.

Свершилось отделение Идеала от объекта, и на передний план выходит объект $a$ без покрова. Художник интерпретирует напрямую посредством объекта влечения, который циркулирует среди обычных объектов и воздействует на наш мир и наши тела, определяя наши привычки, наш образ жизни, а значит, и наши способы наслаждения [Brousse 2009b: 202].

Там, где психоанализ «дедуцирует» (р. 292), помогая субъекту обнаружить иронический зазор в собственном фантазме, современное искусство «продуцирует», создавая своего рода эффект психоза, короткое замыкание столкновения с объектом $a$.

\section{Эпилог}

Небольшая статья М.-Э. Брусс о театре Кастеллуччи (взятая в контексте других ее работ о современном искусстве) - практически единственный пример использования в книге «Театр и психоанализ» языка психоанализа как удобного, полезного для читателя со стороны театра, а не (только) психоанализа, рабочего инструмента. В применении к искусству Кастеллуччи (и, например, Яна Фабра, упомянутого наряду с Кастеллуччи в предисловии к последнему разделу книги) логику исследовательницы можно проиллюстрировать рядом других примеров. Так, в спектакле Кастеллуччи по баховским «Страстям по Матфею» каждая деталь сакрального повествования сопровождается демонстрацией реального, не символического опыта. Крови Христовой соответствует детальная процедура обработки при помощи лабораторного оборудования образца крови, взятого у певца, исполняющего партию Христа; самоубийству Иуды - показ черепа человека, действительно повесившегося в лесу неподалеку от Гамбурга (постановка осуществлена в Гамбургской опере); Тайной Вечере - последнее меню покойного пациента гамбургского хосписа и т. д. В спектакле Яна Фабра «Гора Олимп» после убийства Агамемнона и расчленения его на кровавые, непереносимо реальные куски мяса появляется команда судмедэкспертов, хорошо узнаваемая по полицейским сериалам, и занимается тщательным и неспешным сбором улик «на месте преступления», явно наслаждаясь процессом. Научное и художественное вклиниваются друг в друга, образуя единую поверхность ленты Мёбиуса. Времена старого доброго катарсиса, похоже, прошли. 


\section{Литература}

Архипов 2014 - Архипов Г. А. Понятия диссоциации и вытеснения (Verdrängung) как две парадигматические модели поля мировой психотерапии // Цапкин В. Н., Есипчук М. С., Архипов Г. А. Этюды по психотерапевтической компаративистике. М.: МГППУ, 2014. С. 101-149.

Архипова 2015 - Архипова A. А. Казус Нижинского: опыт психоаналитической интерпретации // С. П. Дягилев и современная культура. Материалы международного симпозиума «Дягилевские чтения». Пермь. Май 2014 г. Пермь: Книжный мир, 2015. С. 7-21.

Лакан 1995 - Лакан Ж. Функция и поле речи и языка в психоанализе. М.: Гнозис, 1995.

Лакан 2010 - Лакан Ж. Семинары. Кн. 10: Тревога (1962/1963). М.: Гнозис; Логос, 2010.

Фрейд 1991 - Фрейд 3. Введение в психоанализ: Лекции. М.: Наука, 1991.

Фрейд 1995 - Фрейд 3. Бред и сны в «Градиве» И. Иенсена // Фрейд 3. Художник и фантазирование. М.: Республика, 1995. С. 138-175.

Фрейд, Брейер 2005 - Фрейд 3., Брейер Й. Исследования истерии // Фрейд 3. Собр. соч.: В 26 т. Т. 1. СПб.: Восточно-Европейский институт психоанализа, 2005. С. 39-67.

Armstrong 1999 - Armstrong R. Oedipus as evidence: The theatrical background to Freud's Oedipus Complex // PsyArt Journal. 1999. January 1. URL: http://psyartjournal.com/article/ show/armstrong-oedipus_as_evidence_the theatrical_backg\#vienna 1911.

Brousse 2009a - Brousse M.-H. "Corps lacaniens": nouveautés contemporaines à propos du stade de miroir // Radio Lacan. 2009. Abril 1. URL: http://www.radiolacan.com/fr/ topic/180/4\#.

Brousse 2009b - Brousse M.-H. L'objet d'art à l'époque de la fin du Beau // La Cause Freudienne: Nouvelle Revue de Psychanalyse. No. 71. 2009. P. 201-205.

Castanet 2015 - Castanet H. Genet. Paris: Max Milo, 2015.

Freud 1953 - Freud S. Psychopathic characters on the stage // The Standard edition of the complete psychological works of Sigmund Freud. Vol. 7 / Ed. and trans. by J. Strachey. London: Hogarth Press, 1953. P. 305-311.

Guéguen 2009 - Guéguen P.-G. The extraordinary case of Jean Genet // Lacanian Ink. No. 34. 2009. P. 94-105.

Lacan 1933 - Lacan J. Motifs du crime paranoïaque: le crime des sœurs Papin // Le Minotaure. 1933. No. 3/4. URL: http://aejcpp.free.fr/lacan/1933-12-12.htm.

Menghi 2008 - Menghi C. Vaslav Nijinsky. L'ottava meraviglia del mondo // Mangiarotti Ch., Menghi C., Egge M. Invenzioni nella psicosi. Macerata: Quodlibet, 2008. P. 167-256.

Hulak 2016 - Hulak F. Logique du sinthome. Mise en pratique. Nîmes: Editions Champ Social de Nîmes, 2016.

Quinet 2010 - Quinet A. L'Inconscient structuré comme un théâtre // Savoirs et clinique. No. 12. 2010/1. P. 188-195. URL: http://www.cairn.info/revue-savoirs-et-cliniques-2010-1page-188.htm.

Wachsberger 1997 - Wachsberger H. Psychose et création: l'art de Nijinsky // Les Feuillets du Courtil. No. 13. 1997. P. 57-64. 


\title{
A STONE OF STUMBLING, OR A ROCK OF SCANDAL? HOW TO TALK ABOUT THEATRE THROUGH PSYCHOANALYSIS
}

\author{
Arkhipova, Anastasia A. \\ Science Editor, \\ The Higher School of Economics Publishing House \\ Russia, 117418, Moscow, Profsoyuznaya str., 33, building 4 \\ Tel.: +7 (495) 772-95-90*12324 \\ E-mail: anastasia.arkhe@gmail.com
}

Review of: Page, C., Koretzky, C., Jodeau-Belle, L. (Eds.) (2016). Théâtre et psychanalyse: Regards croisés sur le malaise dans la civilization. Montpellier: L'Entretemps. 334 p. (In French).

\section{References}

Arkhipov, G. A. (2014). Poniatiia dissotsiatsii i vytesneniia kak dve paradigmaticheskie modeli polia mirovoi psikhoterapii [Dissociation and repression as two paradigmatic models in the field of a global psychotherapy]. In V. N. Tsapkin, M. S. Esipchuk, G. A. Arkhipov. Etiudy po psikhoterapevticheskoi komparativistike [Sketches on Psychotherapeutic Comparative Studies], 101-149. Moscow: MGPPU. (In Russian).

Arkhipova, A. A. (2015). Kazus Nizhinskogo: opyt psikhoanaliticheskoi interpretacii [The case of Nijinsky: an attempt at a psychoanalytic interpretation]. In $S$. P. Diagilev $i$ sovremennaia kul'tura. Materialy mezhdunarodnogo simpoziuma "Diagilevskie chteniia". Perm'. Mai 2014 g. [S. P. Diaghilev and modern culture. The Diaghilev Readings International Symposium. Perm, May 2014], 7-21. Perm: Knizhnyi mir. (In Russian).

Armstrong, R. (1999, January 1). Oedipus as evidence: The theatrical background to Freud's Oedipus Complex. PsyArt Journal. Retrieved from http://psyartjournal.com/article/show/ armstrong-oedipus_as_evidence_the_theatrical_backg\#vienna 1911.

Brousse, M.-H. (2009a, April 1). “Corps lacaniens”: nouveautés contemporaines à propos $d u$ stade de miroir. Radio Lacan. Retrieved from http://www.radiolacan.com/fr/topic/180/4\# (In Spanish).

Brousse, M.-H. (2009b). L'objet d'art à l'époque de la fin du Beau. La Cause Freudienne: Nouvelle Revue de Psychanalyse, 71, 201-205 (In French).

Castanet, H. (2015). Genet. Paris: Max Milo. (In French).

Freid, Z. (1991). Vvedeniye v psikhoanaliz: Lektsii [Introduction to psychoanalysis: Lectures. Trans. from Freud, S. (1976). Vorlesungen zur Einführung in die Psychoanalyse und Neue Folge. Frankfurt am Main: S. Fischer Verlag]. Moscow: Nauka. (In Russian).

Freid, Z. (1995). Bred i sny v "Gradive" I. Iensena [Delusions and dreams in Jensen's Gradiva. Trans. from Freud, S. (1969). Gesammelte Werke (Vol. 7), 29-122. Frankfurt am Main: S. Fischer Taschenbuch Verlag]. In Z. Freid. Khudozhnik i fantazirovanie [Artists and daydreaming], 138-175. Moscow: Respublika. (In Russian).

Freid, Z., Breier I. (2005). Issledovaniia isterii [Studies on hysteria. Trans. from Breuer, J., Freud, S. (1999). Studien über Hysterie. Frankfurt am Main: S. Fischer Taschenbuch Verlag]. In Z. Freid. Sobranie sochinenii [The complete works] (Vol. 1), 39-67. St. Petersburg: Vostochno-Evropeiskii institut psikhoanaliza. (In Russian).

Freud, S. (1953). Psychopathic characters on the stage. In J. Strachey (Ed. and trans.). The Standard edition of the complete psychological works of Sigmund Freud (Vol. 7), 305-311. London: Hogarth Press.

Guéguen, P.-G. (2009). The extraordinary case of Jean Genet. Lacanian Ink, 34, 94-105. 
Hulak, F. (2016). Logique du sinthome. Mise en pratique. Nîmes: Editions Champ Social de Nîmes. (In French).

Lacan, J. (1933). Motifs du crime paranoïaque: le crime des sœurs Papin. Le Minotaure, 1933(3/4). Retrieved from http://aejcpp.free.fr/lacan/1933-12-12.htm. (In French).

Lakan, Zh. (2010). Seminary [Seminars] (Book 10) Trevoga (1962/1963) [Anxiety. Trans. from Lacan, J. (2004). Le Seminaire, Livre X: L'angoisse (1962/1963). J.-A. Miller (Ed.). Paris: Editions du Seuil]. Moscow: Gnosis; Logos. (In Russian).

Lakan, Zh. (1995). Funktsiia i pole rechi i iazyka v psikhoanalize [The function and field of speech and language in psychoanalysis. Trans. from Lacan, J. (1956). Fonction et champ de la parole et du langage en psychanalyse. Rapport du Congrès de Rome tenu à l'Istituto di Psicologia della Universitá di Roma les 26 et 27 septembre 1953. La psychanalyse, 1, 81-166]. Moscow: Gnosis. (In Russian).

Menghi, C. (2008). Vaslav Nijinsky. L'ottava meraviglia del mondo. In Ch. Mangiarotti, C. Menghi, M. Egge. Invenzioni nella psicosi, 167-256. Macerata: Quodlibet. (In Italian).

Quinet, A. (2010). L'Inconscient structuré comme un théâtre. Savoirs et clinique, 2010(1) = (No. 12), 188-195. Retrieved from http://www.cairn.info/revue-savoirs-et-cliniques-2010-1-page188.htm. (In French).

Wachsberger, H. (1997). Psychose et création: l'art de Nijinsky. Les Feuillets du Courtil, 13, 57-64. (In French).

To cite this article:

Arkhipova, A. A. (2017). Kamen' pretknovenita ili skala skandala? (KaK GOVORIT' O TEATRE S POMOSHCH'IU PSIKHOANALIZA) [A STONE OF STUMBLING, OR A ROCK OF SCANDAL? How to talk about theatre through PSYChOANalysis]. ShaGi / STEPS, 3(3), 219-234. (In RuSSIAN). 